\title{
Strengthening of Health Locus of Control could Increase the Independence of Post Stroke Patients in Implementing the Daily Activities at Home
}

Ali Hamzah* and Sugiyanto

Bandung Nursing Department, Bandung Health Politechnic, Indonesia

*Corresponding author: Ali Hamzah, Bandung Nursing Department, Bandung Health Politechnic, Indonesia, E-mail: alihamzahbandung@yahoo.co.id Received date: February 3, 2014, Accepted date: April 4, 2014, Published date: April 8, 2014

Copyright: () 2014 Hamzah, et al. This is an open-access article distributed under the terms of the Creative Commons Attribution License, which permits unrestricted use, distribution, and reproduction in any medium, provided the original author and source are credited.

\begin{abstract}
According to the data released by the Ministry of Health of Indonesia in 2009 shown that stroke was reported as the first number cause of death in patients who's hospitalized and it placed the eleventh rank of the most diseases in outpatient wards. Strokes often cause a lot of problems, especially interferes in the functioning of the body movement then prequently lead to disability, dependence on the other and inability to carry out daily activities. It is not only the healing process that takes time but also stroke treatment and rehabilitation does too gradually it leads to boredom and frustration. Furthermore, if the patient want to return to their productive phase they have to be confidence to have a self-control of their health problems (health locus of control) so that their level of independence in carrying out their daily activities can be improved. This study is aimed to determine the effect of strengthening health locus of control to the independence of post stroke patients in carrying out daily activities at home. The research method used a quasi-experimental with pre and post test without control design, and used the 31 poststroke patients who are undergoing treatment at the Polyclinic stroke of Al Islam Hospital Bandung, Indonesia, as sample. The samples were taken by purposive sampling technique. Data analysis consisted of univariate analysis using the mean score and standard deviation as well as bivariate analysis using t-test dependent. Based on the analysis obtained that the strengthening of the Health locus of control influence was highly effectively to increase the independence of post stroke patients in carrying out his daily activities, so the nurse suggested that the strengthening health locus of control should be continued to be implemented to the post- stroke patients to continue treatment at home in order to increase their independence.
\end{abstract}

Keywords: Strengthening health locus of control; Independence in implementing daily actvities; Stroke

\section{Introduction}

Based on the data taken from the Ministry of Health of Indonesia in the year 2009 shown that stroke was considered as the first cause of death to hospitalized patients and it ranked as the eleventh most diseases in outpatient wards. Meanwhile, according to report done by the Fundamental Health Research in 2007 stroke was prevailed in Indonesia was about 8.3 per 1000 , in the province of West Java was $0.9 \%$, and in Bandung city reached $1.1 \%$.

However, the results made by Thomas and Santoso (2003) in Dr. Kariadi hospital Semarang was only $7.7 \%$ of suffer can perform their daily activities independently after they had been undergone treatment in such particular hospital [1]. While the remaining, $77.8 \%$ suffer need family assistance to be able to perform their daily activities and $22.2 \%$ was highly dependent on their family to perform daily activities. In regard, to the stroke patients who's undergone advanced treatment program requires the presence of a health locus of control/HLoC.

The health Locus Of Control is the degree of belief in one's health that his health is determined by internal factors or external factors. It means that the patient him self feels responsible for his health. Several studies related to the health locus of control had been done before; Nurina Dewi Pratita used the method of correlation studies to assess the relationship of spousal support and the health locus of control with compliance in undergoing the treatment of type 2 diabetes, the obtained results indicated that there was a high relationship (close) between spousal support and the health locus of control with compliance in undergoing the treatment of type 2 diabetes $(r=0884$ $\mathrm{p}=0.0001$ ) [2]. Similarly, another research conducted by Yunita Mandasari about the relationship health locus of control among smoker and assertive behavior in teen, the results obtained $\mathrm{p}$ value = 0.0005 , which mean that there was a significant relationship between significant others health locus of control and assertive behavior in adolescents who smoke [3].

Referring to such metters, the importance of health locus of control in determining compliance patient post- stroke treatment program will also directly determine their independence in meeting his daily needs the further research on the influence of these factors HLoC. Hence, the purpose of this study is: "to determine the effect of strengthening of the health locus of control to independence of poststroke patients in carrying out their daily activities at home".

\section{Conceptual framework}

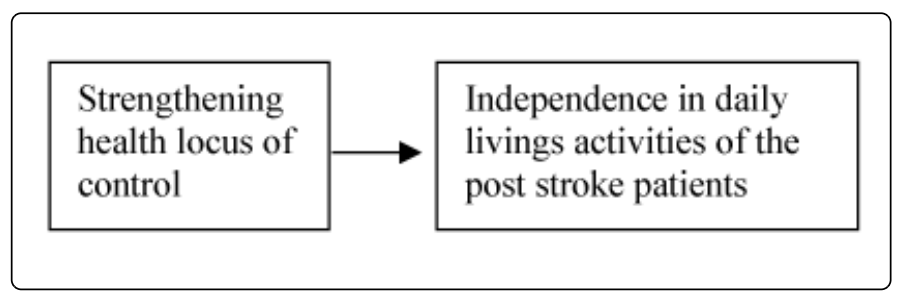


Page 2 of 4

\section{Definition of term}

Strengthening of Health Locus of Control (HLOC), an independent variabel is kind of effort done by researchers to enhance a patient's self confidence level to have a self control on health of post-stroke patients, through the approach of giving educational home visits twice a week, counseling once and motivation once a week, for at least 45 minutes.

Consequently, the independence level to carry out daily activities done by post-stroke patients that is considered as a dependent variable was performing the activities of eating, bathing, dressing ornate, defecation, urination, toileting, moving from bed to chair or conversely, move, and up or down stairs, both before and after strengthening health locus of control as measured by observation using the Barthel index. The results of a range of values that range from $0-100$, the higher the value obtained patients show that the patients increasingly independent, and it is in ratio scale.

\section{Research Methodology}

This study used a quasi experiment with pre and post test design without control. It has been implemented since September 2012 up to October 2013, using the 31 post- stroke patients who were undergone a treatment at the polyclinic stroke in Al Islam hospital Bandung. The data was obtained by using purposive sampling technique. The patients who were selected are undergoing post-stroke treatment program. It was not taken from hemoraghic stroke criteria. The condition of the patient is conscious and calm, cooperative, able to listen and speak clearly and willing to be respondent. Data collection is begun by identifying post- stroke patients who meet the inclusion criteria, then patients who met the inclusion criteria provided an informed consent and asked approval is for being the respondents. Subsequently measured respondent level of independence in performing daily activities at home before being given treatment (pretest), and then do the strengthening health locus of control, consisting of a package modul as much as 4 times, consist of 2 times a week for education program and each education program need 45 minutes with the topic: care and stroke rehabilitation program at home and efforts to improve post- stroke patient independence in performing activities of daily living, the next was given counseling 1 times (45 minutes) and finally was given motivation to the patient 1 times ( 45 minutes) too, due home visit to each patient's residence. After patients completed a whole series of these treatments directly measured the level of independence in performing activities of daily living as a data posttest. Data processing was done by step: editing, coding, entrying, cleaning and processing, data. Further data analysis through univariate analysis using the mean and standard deviation as well as bivariate analysis using t-test dependent.

\section{Result}

\section{Univariate analysis}

\section{Respondent characteristic}

\begin{tabular}{|l|l|l|l|}
\hline & Respondent characteristic & $\mathbf{f}$ & $\%$ \\
\hline $\mathbf{1 .}$ & Age: & & \\
\hline & Adult (18-45 years old) & 1 & 3,23 \\
\hline & Pre elderly (46-59 years old) & 6 & 19,35 \\
\hline
\end{tabular}

\begin{tabular}{|l|l|l|l|}
\hline & Elderly ( $\mathbf{6 0}$ years old) & 24 & 77,42 \\
\hline & Number & 31 & 100 \\
\hline $\mathbf{2}$ & $\begin{array}{l}\text { Experienced of having patient in stroke } \\
\text { frequency: } \\
\mathbf{1} \text { times }\end{array}$ & 12 & 38,71 \\
\hline & $\mathbf{2}$ times & 19 & 61,29 \\
\hline & Number & 31 & 100 \\
\hline $\mathbf{3 .}$ & Patient relationship with the family: & & \\
\hline & Spouse (husband/wife) & 19 & 61,29 \\
\hline & Children & 12 & 38,71 \\
\hline & Number & 31 & 100 \\
\hline
\end{tabular}

Table 1: Respondent Characteristic (Post Stroke patient who undergo to Polyclinic stroke of Al Islam hospital)

Referring to Table 1 it appears that patient post-stroke who are undergoing treatment at the clinic of the stroke program Al Islam Hospital Bandung majority $(77.42 \%)$ categorized as elderly age ( $\geq 60$ years), most of them also had suffered a stroke $\geq 2$ times and only a small part for the first time had suffered a stroke and suffered a stroke during their general lives with her partner (husband/wife) at home.

Mean score independence in daily activities of the post stroke patients before and after streghtening health locus of control/HLoC

\begin{tabular}{|l|l|l|l|}
\hline Indepedence of Post Stroke Patient & Mean & N & Sd \\
\hline $\begin{array}{l}\text { Before strengthening health locus of } \\
\text { control }\end{array}$ & 62.74 & 31 & 26.23 \\
\hline $\begin{array}{l}\text { After strengthening health locus of } \\
\text { control }\end{array}$ & 46.61 & 31 & 22.38 \\
\hline
\end{tabular}

Tabel 2: Mean score of Indepedence Post Stroke Patient (before and after strengthening health locus of control)

Based on Table 2 the mean score of post-stroke patient independence in performing their daily activities at home before being given the strengthening HLOC is 46.61 with a standard deviation of 26.23 and after strengthening HLOC increased to 62.74 with a standard deviation of 22.38 .

\section{Bivariate analysis}

Results of t-dependent test analysis as shown in Table 3.

\begin{tabular}{|l|l|l|l|l|l|}
\hline Data & $\begin{array}{l}\text { Avg } \\
\text { Mean }\end{array}$ & Sd & $\begin{array}{l}\text { Std. Error } \\
\text { Mean }\end{array}$ & $\mathbf{t}$ & $\mathbf{p}$-Value \\
\hline $\begin{array}{l}\text { Post Test - Pre } \\
\text { Test }\end{array}$ & 16.13 & 10.54 & 1.89 & 8.517 & 0.0001 \\
\hline
\end{tabular}

Tabel 3: Analysis of the average difference before and after intervention strengthening health locus of control to post-stroke patients. 
Table 3 shows that the difference in average scores indepedence of the post stroke patient before and after streghtening HLoC is 16,13 with standard deviation is 10,54 , a value of $\mathrm{t}=8,517$ and 0.0001 probability value $\leq 0.05$. These results indicate that there is a significant effect of strengthening to the independence HLOC on improving post-stroke patients in carrying out his daily activities at home.

\section{Discussion}

The results indicate that efforts to strengthen HLOC through 4 types implementation two times giving education, counseling and motivation by home visit. It is proven to increase on average of independence significantly. This suggests that in addition to the familiar program implemented by the health care team in the hospital such as blood pressure control, continuing treatment and medical rehabilitation programs, nurses also need to make another effort, especially in strengthening and improving the health locus of control patient in dealing with the problem at hand stroke so the patients have confidence with high motivation, strong spirit and exercise, as a result their level of dependence on others reduce or having self independence. Through strengthening this HLOC a patient has given the opportunity to convey his feeling or expressing emotions therefore the patient feel more recognized, listened to his complaint and made him aware of changes, getting solutions and motivation to pace his problem.

Referring to the opinion Wallston and Walston (2002) that "health locus of control is influenced by several factors, including the age factor, older the patient is, the higher the belief of HLoC is. In accordance to the theory many strokes patients occur in middle age above. However, in this study found a very young age of stroke patients at the age of 31 years old. When associated with research, it turns out the age factor in this study has a strengthening effect also affects HLOC, where the young age of the patient, the easier and excited in doing exercises so it's easier HLOC strengthened. Some patients at adult age categories (18 - 45 years) and pre- elderly (46 - 59 years) responded well when given training Range Of Motion (ROM) and their motivation to improve HLOC, some of them made progress, due to his productive age. This can be seen at the second and third visits generally they have increased ability to perform daily activities.

Besides the age factor, the influence of the strengthening HLOC to be independence in carrying out their daily activities to the poststroke patients are also influenced by the experience of having patient in stroke frequency. According to the research Cadena et al. (2011), in examining the relationship of locus of control with work experience, found that "experience can change a person's belief in self-control" [4]. In this study, the majority $(61.29 \%)$ of respondents had suffered a stroke the same experience or more than 2 times.

Experience of suffering a stroke more than 2 times will affect the patient's ability to accept and digest the information given by the researchers in the form of education, counseling and motivation due to the many functions of neurons that have been damaged. Smeltzer (2002) and Sylvia Anderson (2006) revealed that "more often patient having a stroke, the risk of damage to the neurons in the brain affected and the more widespread", in which it will also influence the noble functions including a memory function and motoric patient. In contrast to the small proportion of respondents (38.71\%) for the first time having stroke, the risk of damage to the neurons in his brain will be fewer and smaller, so that the ability of some of its noble function, especially memory can still have function properly when handling fast and proper [5].

In addition, the presence and involvement of people who matter to patient especially from spouse (husband/wifes) is very important in the success of this intervention HLOC strengthening the independence of post- stroke patient. Referring to Table 1, the majority (61.29\%) of respondents suffered from stroke during their generally treatment by her partner (husband/wife) or if the deceased spouse was a minority (38.71\%) of respondents cared for by children. Based on the observations in most patient researchers got positive support and motivation, especially attention from both families of couples (husband/wife) or their children apperently increase. Average the level of independence, otherwise the patient who has lack off support is less concerned from his family because of busy working or over protective than the patient has generally less motivated and willing to attempt to break away from dependence of the family, hence the average level of independence less likely to increase or even stagnant. Thus the stronger the family support for the patient, the faster the patients can achieve independence to carry out their daily activities.

Simirarly, the research conducted by Nurina Dewi Pratita (2012) shown that there is a relationship between spousal support and the Health Locus Of Control with compliance in undergoing the treatment of type 2 diabetes $(\mathrm{r}=0884$ and $\mathrm{p}=0.0001)$ [2]. Likewise, the results of research conducted Yunita Mandasari (2011) of the relationship health locus of control and assertive behavior of a teen smoker, shown a significant correlation between significant others health locus of control and assertive behavior in adolescents who smoke $(\mathrm{p}=0.005)$ [3]. The results are not much different shown by Enejoh A Victor and Karick Haruna (2012) in this study of Relationship between health locus of control and sexual risk behavior concluded that there was statistically significant effect HLOC on risky sexual behavior $(\mathrm{p} \leq 0.05)$.

The level of health locus of control is different for each person, this is due to differences in assessment and experiences during his life span. Some patients displayed more positive behavior, when they were motivated to maintain their life by getting the treatment and rehabilitation programs on a regular basis. So that, they feel that they are still able to perform their activities like everyone else, even a little. Here is encourage them to seek independently in carrying out their daily activities needs. However the majority of patients who have a pessimistic sense of the condition of his health, they need to be encouraged by others because they thought that he was not able to do anything else because all that has been determined by God [6]

According to these result, it is necessary to strengthen HLOC ifor patients who have chronic diseases and requires continuoustly treatment, such as: the stroke patients need to be handled by the nurse that the patient can continue to be motivated to continue treatment and rehabilitation programs that ultimately will be self-sufficient in patient health control, especially in carrying out daily activities [7-12].

\section{Limitation}

This research study has some limitations especially on the research design that didn't use control group or another group intervention, because we had very difficult to find appropriate patients criteria and we couldn't control confounding factors such as medication program.Therefore, the result couldn't compare with the others and it will influence the conclussion [13-22]. 
Citation: Hamzah A, Sugiyanto (2014) Strengthening of Health Locus of Control could Increase the Independence of Post Stroke Patients in Implementing the Daily Activities at Home. J Nurs Care 3: 152. doi:10.4172/2167-1168.1000152

Page 4 of 4

\section{Conclusion}

Strengthening health locus of control will effectively be increase self independence in performing daily activities at home for the poststroke patients who were adjusted to the Polyclinic stroke of Al Islam hospital Bandung.

\section{Suggestions}

Nurses need to continue an integration effort to strengthen the HLOC treatment for the post stroke patients in their home in order to increase their independence, by integrating these efforts with the home care program.

Nurses also must cooperate and always involve which the family in providing support to post-stroke patients who were treated at home so that patients can continue to improved their HLOC and independence of him.

\section{Acknowledgements}

Great appreciation is given to Director of Bandung Health Polytechnic, and Chairperson of Bandung Nursing department who has supported and giving budget for this research project. We would also like to thank to the Director and the head of nurse of Bandung $\mathrm{Al}$ Islam hospital, in Bandung, who has given us permission to conduct research. I am gratefully indebted for all of patients and family members of the stroke patients who participated in this study.

\section{References}

1. Santoso, Thomas A (2003) Kemandirian Aktivitas Makan, Mandi Dan Berpakaian Pada Penderita Stroke 6-24 Bulan Pasca Okupasi Terapi. Skripsi. Semarang: Universitas Diponegoro.

2. Pratita ND (2012) Hubungan Dukungan Pasangan Dan Health Locus Of Control Dengan Kepatuhan Dalam Menjalani Proses Pengobatan Pada Penderita Diabetes Mellitus Tipe-2, Jurnal Ilmiah Mahasiswa Universitas Surabaya Vol.1 No.1.

3. Mandasari Y (2011) Health Locus of Control Relationships and Assertive Behavior In smoker Teens, Gunadarma University Library.

4. David Cadena BS, Sandra B, Inez Cruz MSW, Ashok K, Robert F (2011) Correlation between locus of control and opportunities for health behaviors, The University of texas Health Science Centre at San Antonio.
5. Price, Sylvia A (2006) Patofisiologi Konsep Klinik Proses-proses Penyakit Edisi 4. Jakarta : EGC.

6. Lau RR (1982) Origins of health locus of control beliefs. J Pers Soc Psychol 42: 322-334.

7. Brenda GB, Suzanne CS (2002) Brunner \& Suddarth: Text Book of Medical Surgical Nursing, W.B. Sounders. Philadelphia.

8. Depkes (2009) Badan Penelitian dan Pengembangan Kesehatan Departemen Kesehatan, Republik Indonesia.

9. Departement of Psycology and School of Public Health (1999) Does locus of control moderate the effect of tailored health education materials?, St Louis University, St Louis, MO 63108, USA.

10. Dinkes TK I Jawa Barat (2007) Profil Kesehatan Jawa Barat. Bandung : Dinkes Provinsi Jawa Barat.

11. Schlenk EA, Hart LK (1984) Relationship between health locus of control, health value, and social support and compliance of persons with diabetes mellitus. Diabetes Care 7: 566-574.

12. Mulyatsih E (2006) Stroke, Petunjuk Praktis bagi Pengasuh dan Keluarga Pasien Pasca Stroke, Jakarta: Balai Penerbit FKUI.

13. Victor EA, Haruna K (2012) Relationship between health locus of control and sexual risk behavior. Retrovirology 9: P62.

14. Ida F (2009) Mengantisipasi Stroke Petunjuk Mudah, Legkap dan Praktis Sehari-Hari. Yogyakarta: Buku biru.

15. Indriyati (2009) Hubungan Activity Daily Living (adl) Berdasarkan Indeks Barthel Dengan Tingkat Depresi Pada Pasien Stroke Di Bangsal Anggrek 1 RS Dr. Moewardi Surakarta. Skripsi. Surakarta: Universitas Muhamadiyah Surakarta.

16. Muhammad I (2010) Fisioterapi Bagi Insan Stroke. Yogyakarta:Graham Ilmu.

17. Muttaqin A (2008) Asuhan Keperawatan Klien Dengan Gangguan Sistem Persarapan. Jakarta : Salemba Medika.

18. Niven ON (2002) Psikologi Kesehatan Pengantar Untuk Perawat dan Professional Kesehatan Lainnya. Jakarta: EGC.

19. Nursalam (2008) Konsep \& Penerapan Metodologi Penelitian Ilmu Keperawatan: Pedoman Skripsi, Tesis, dan Instrumen Penelitian. Jakarta; Salemba Medika.

20. Pinzon R, Laksmi A (2010) Awas Stroke! Pengertian, Gejala, Tindakan, Perawatan dan Pencegahan. Yogyakarta: Andi.

21. http://www.yastroki.or.id/read.php?id=300.

22. Health Locus of Control Scales (2002) In H. Lefcourt (Ed.) Research With The Locus of Control. New York: Academic Press. 